ARIC

From: Karima Hessami <karima.hessami@undp.org>

To:_<gender@brain.net.pk>; <npourzand@unicef.org>; Katharina Lumpp<lumpp@unhcr.ch>; Homa Sabri<unchs@isb.paknet.com.pk>; Nancy Dupree<aric@brain.net.pk>; GraberR

<GraberR@whoafg.org>; Sippi Azerbaijani-Moghadam <womensco@pes.comsats.net.pk>

Sent: Friday, June 29, 2001 10:08 AM

Subject: SG report on the situation of women and girls in Afghanistan

$>$ From Norah Niland

Dear Colleagues,

I have, literally, just received this; I have not read it but given the very short timeframe I am forwarding it to you for any comments you may have. I am sorry but it appears that I need to receive these by first thing on Monday morning (02 July) so i can forward them to Geneva which needs to finalize the report.

With thanks for your understanding on this, regards, norah

Original Message

Subject: SG report on the situation of women and girls in territories occupied byAfghan armed groups

Date: Thu, 28 Jun 2001 22:06:58 +0200

From: "Christina Saunders" <csaunders.hchr@unog.ch>

To: norah@UNDPAFG.ORG.PK, "Norah Niland"

<Norah_Niland.UNCHR@unog.ch>,karima.hessami@undp.org

Dear Norah,

please find pasted below a draft report for the sub-commission on the

situation of women and girls in territories occupied by

Afghan armed

groups. You will see that it still needs work but I thought

that by

sharing it with you at this stage it could be finalized

faster. It is brief

as it will merely provide new information not already

mentioned in the

comprehensive CSW report on the same issue, which will be

circulated at

the Sub-Comm as a reference document. The draft has been

based on

information provided by $\mathrm{KH}$ to the $\mathrm{CHR}$, the UN Weekly Updates

and the PHR

report. 
Please kindly revise, cut and add where appropriate.

As the other report contains the substantive overview of the situation

how much material do you think we should include in this one?

a lot of the information is from UN Weekly Update is that

\section{ok as a}

source?

please cut out any politically sensitive material or

material you think

is irrelevant?

what structure should the report take? order?

chronological or by

subject?

The concluding remarks are particularly important as they are normally

picked up for the resolution thus your insight as to what the

sub-commission should recommend would be useful.

I have also included some specific queries in the text in bold.

As usual we are working to a tight deadline so please let me have your

comments asap, preferably before Sunday and if possible make changes

directly on the text, so that we can submit the report to

docs control in

time for editing/translation.

Many thanks for your usual help and guidance.

Best regards, Christina

DRAFT 27 June 2001

Sub-Commission on the Promotion and Protection of Human

Rights

Report of the Secretary-General on the situation of women

and girls in the

territories occupied by Afghan armed groups

I. Introduction

The present report is submitted in accordance with resolution 2000/11, in which the Sub-Commission requested the Secretary-General to report on the 
situation of women and girls in the territories controlled by Afghan armed

groups.

This report is an update to the report of the Secretary-General submitted

to the forty-fifth session of the Commission on the Status of women in

March 2001 entitled, The situation of women and girls in Afghanistan

(E/CN.6/2001/2/Add.1). The earlier report provides an overview of the

current situation of women and girls in Afghanistan against the background

of the deteriorating socio-economic conditions, continued conflict and

discriminatory edicts issued by the Taliban authorities. The report also

contains information about actions taken by the United

Nations system and

assistance community in Afghanistan to improve the situation of women and

girls in Afghanistan as recommended in the Economic and Social Council

resolution. It also identifies areas in which further

efforts are needed.

To avoid duplication the present report will only include relevant new developments/material since March and should be read with the earlier substantive report, which will be circulated at the

Sub-Commission as a

reference document.

In recent months a number of resolutions have been adopted on the situation

of women and girls in Afghanistan:

At its forty-fifth session (March 2001) acting without a vote, the

Commission on the Status of Women recommended to the

Economic and Social

Council to adopt a resolution on discrimination against women and girls in

Afghanistan. It strongly condemned the continuing grave violations of the human rights of women and girls, including all forms of discrimination against them in all areas of the country, particularly in those under the 
control of the Taliban. It also condemned the continued restrictions on

women's access to health care and the systematic violation

of their human

rights in Afghanistan, including the restrictions on access

to education

and employment outside the home, on freedom of movement and

on freedom from

intimidation, harassment and violence.

At its fifty-seventh session (April 2001) the Commission on

Human Rights

adopted resolution 2001/13 on the situation of human rights

in Afghanistan,

without a vote. In which it strongly condemned the mass

killings and

systematic human rights violations against civilians and persons deprived

of their liberty, for reasons related to the armed conflict

and noted with

alarm the resumption by the Taliban of a wider conflict

during the past

summer, resulting in the massive forced displacement of the

civilian

population. It also noted with deep concern the continuing

pattern of human

rights violations in Afghanistan and the continuation of

armed hostilities

and the complex nature of the conflict, including its

ethnic, religious and

political aspects, which had resulted in extensive human

suffering and

forced displacement. The continuing grave violations of the

human rights of

women and girls were condemned, and all Afghan parties were

urged to

respect fully all human rights. The Commission decided to

extend the

mandate of the Special Rapporteur on the situation of human

rights in

Afghanistan for one year.

II. Background information-the ongoing conflict do you

think in this type

of update I should limit the amount of info about the

conflict? and instead

just stick to new developments? I included it because it is

not covered in

much detail in the CSW report. 
The ongoing conflict is making a catastrophic humanitarian situation even

worse. The conflict and its destructive impact on

communities and the right

to life, and the accumulated and indirect effects of war contribute to a

massive human rights deficit. This deficit includes the denial of the right

to food, the right to health and the right to education. Nor do Afghans

enjoy freedom from fear or freedom of association. The

collapse of civil

society and the limited ability of Afghans to participate in or influence

decision-making have a direct and negative impact on their right to life

and other rights essential for livelihood and survival with a modicum of

dignity. Women and girls suffer disproportionately in the realization and

enjoyment of all their rights and there are few indications that this will improve significantly any time in the near future.

Despite an agreement in November 2000 by the two warring parties to

initiate a process of dialogue under the Secretary-General's good offices, aimed at bringing about, in the shortest possible time, an end to the armed conflict in Afghanistan through political means.

Unfortunately, both

parties have engaged in military operations resulting in resumption of conflict in different parts of Afghanistan, extending from July 2000 to

date.

All the warring parties have been guilty of grave breaches of international humanitarian law. The involvement of Afghanistan's neighbours and other states in providing weapons, ammunition, fuel and other logistical support support their war making. State and non-state actors across the region and beyond continue to provide new arms and other material as well as training and advisory assistance. The arms provided have been directly implicated in 
serious violations of international humanitarian law. These include aerial

bombardments of civilian targets, indiscriminate bombings, rocketing and other artillery attacks on civilian populated areas, massacres involving reprisal killings of civilians, summary executions of prisoners, and torture.

Reports supported by reliable eyewitnesses document some of the summary executions and massacres carried out in January 2001 in Yakawlang. These reports indicate that in the taking and re-taking of Yakawlang breaches of humanitarian law were committed by both parties as they violated the neutrality of medical facilities in the district and disregarded the rights of civilians to be treated as non-combatants. Yakawlang was captured by the

United Front forces (Hezbe Wahdat and Harakat Islami) on 28 December 2000

but was re-captured by the Taliban in early January 2001.

Taliban forces

reached the district centre of Nayak in the morning on 8 January 2001.

Following the re-taking, there are reports of mass arrests followed by summary executions carried out between 8 to 12 January 2001. A number of aid agency personnel and a United Nations staff member were among those who were killed. The Human Rights Watch report, published on 19 February 2001, has identified civilian victims who include a number of aid workers and staff of international humanitarian agencies, hospitals and local relief and assistance organizations. This report indicates that search parties were organized to round up male civilians following house-to-house searches. Those rounded up were detained and many of them, the total number being estimated at several hundred, were reportedly executed. It is reported that a number of Hazara elders who came to intercede with the 
Taliban were also killed. Some of the execution sites identified include the outside of a relief agency in Nayak, the outside the district hospital, the ravine behind the mosque in the old bazaar area, the outside the prayer hall of Mindayak village and Qala Arbab Hassan. A number of sites of mass graves are also identified. Also, the identities of commanders who present in the area at the relevant time are available in these reports.

On 16 February 2001 the United Nations High Commissioner for Human Rights

published a statement on Afghanistan. In view of the pattern of repeated massive violations of human rights and humanitarian law, the High

Commissioner called upon the international community to establish an

independent international inquiry into the massacres and other grave human

rights violations committed by parties to the armed conflict in

Afghanistan. This statement was made in the context of reports, among

others, of summary execution of civilians by Taliban forces in the

Yakawlang district of the province of Bamyan in January 2001.

It is now recognized that the impunity enjoyed by those who have been

responsible for ordering and carrying out the massacres and summary

executions and the absence of accountability for such gross violations of

human rights and grave breaches of humanitarian law has contributed to the repeated occurrence of such violations. There is thus a growing opinion

that in order to deter and prevent the occurrence of such atrocities, an

effective international initiative is called for to expose and hold to account those responsible for war crimes, breaches of international humanitarian law and gross violations of human rights. International 
cooperation would be needed to deny impunity and enforce accountability by

developing mechanisms to undertake full investigation to gather evidence

and to identify those responsible in order that they may be brought to

justice. The Taliban authorities and the Islamic State of Afghanistan will

be expected to respect their obligation to cooperate in the carrying out of

these investigations. The findings of these investigations

would provide a

basis for enforcing accountability through appropriate

mechanisms at the

national and international levels.

On 18 June 2001 the Secretary-General// expressed my dismay at the

persistent failure of the warring parties to abide by

international

humanitarian norms and to hold those responsible for gross

violations of

human rights accountable for their actions. Reacting to the

alarming

reports from Afghanistan of indiscriminate bombing,

including attacks on

the District Hospital and local aid agency facilities, and

violence against

civilians, during the take-over of Yakawlang by Taliban

forces on 11 June.

As well as the reported widespread burning of homes and

other property and

the large number of civilians said to have been detained and

removed from

the area. I urged the international community and human

rights

organizations to explore new approaches that would prevent

further abuses

and put an end to the climate of impunity.

III.Discriminatory gender policies

The policy and practices of the Taliban authorities, which

exacerbate the

discrimination already suffered by Afghan women, continue to

be a major

concern. Women's mobility, including their ability to

undertake paid

employment outside the home, continues to be severely

restricted. 
The recently released population-based study by Physicians for Human Rights

(PHR) documents the degree to which Afghan women perceive that violations

of human rights by the Taliban regime are responsible for affecting their

health and well-being. It is one of the first studies ever to assess the

Afghan people's attitudes on women's human rights and the importance of

these rights for community health and development in

Afghanistan. While

noting that the causes of women's suffering in Afghanistan

may be related

to a number of factors, and not simply the effects of

Taliban policies, the

study focused particularly on the effects of official

policies of

discrimination against women because of their unique

significance. The PHR

underline that policies restricting women's rights are not

the product of

years of conflict and social and economic deprivation, which

are arguably

difficult to resolve; they are man-made policies that can be revoked as

easily and swiftly as they came into being. Such policies

are as

detrimental to the health and development of the Afghan

people as they are

to the credibility of the Taliban regime. They report that

although the

Taliban claims that their gender policies are rooted in

Afghan history and

culture, this claim is contradicted by the views of the

Afghan women and

men in the PHR study. Over $90 \%$ of Afghan women and men

sampled in PHR's

population-based surveys strongly support rights of women

restricted by

the Taliban regime, including equal access to education and work

opportunities; freedom of expression, legal protection for

women's human

rights and participation in government; and agree that

women's human rights

issues should be included in peace talks. Approximately $80 \%$ of women and

men agreed that women should be able to move about freely 
and that the

teachings of Islam do not restrict women's human rights.

Seventy-five

percent of women and men expressed that women should be able to associate

with people of their own choosing. PHR's finding that the vast majority of

both Afghan women and men do support women's rights provides

critical

insight into the extent to which Taliban policies fail to

represent the

interests of the Afghan people.

IV.Women and girls in the Rural Areas Q. I included this because of the

comment made by WFP on the CSW report do you think we should

have a

separate section on rural areas or just try to incorporate

it into the body

of the text, and if so where?

Women and girls in remote rural areas while largely escaping the imposition

of Taliban edicts, which are implemented most rigorously in

the urban

areas, are however particularly affected by other factors

that are often

overlooked. As an example of the situation in rural areas I

have chosen the

isolated district of Shar-i-Buzurg in Badakhshan province

which is facing a

precarious situation requiring an emergency response

following two

consecutive years of drought. This situation is particularly

difficult in

terms of food security, and the situation is aggravated by

the fact that

the district has no road links to the outside world and can

only be reached

on horseback or on foot, while $97 \%$ of the arable land is

rain fed. Finally,

the ongoing conflict and the precarious economic situation

prevents the

district from drawing assistance from more developed

neighbouring areas.

ACTED (please spell out), present in the area since 1998,

implemented a

thorough survey of the area from 5 to 25 May 2001, surveying

every one of 
the 63 villages in the district. This evaluation, the first comprehensive

one to be undertaken in the area presents an overview of the situation with

special focus on the food situation, the medical situation, water and

sanitation, and agriculture. The findings underlined the emergency nature

of the situation especially in terms of the food deficit, the exhaustion of cropping strategies, and the lack of seeds for the next harvest. In some

areas, up to $10 \%$ of the local population have already left their homes and

gone to swell the number of IDPs in Tarkhar and Baghlan or have left for

Pakistan and Iran. However, because of the remoteness of the district and

the unavailability of cash, it has been noticed that, even if the situation

is particularly precarious, the local population is waiting for the last

moment before leaving their villages. If steps are not taken to address the

situation in this district, it can be estimated that a

significant portion

of the local population could become displaced in the next months.

ACTEDs survey found that the food shortage has already reached a state of

crisis and is poised to worsen in months to come. Given the fact that only

about $42 \%$ of the available land had been sown for the first spring harvest

in the first place, the population is likely to face serious food shortages

for the rest of the year aggravated by the fact that the local population

has already sold an estimated 50 to $70 \%$ of its livestock to cope with cash

and food deficiencies. The survey revealed that most families have eaten

the seeds that they normally keep for sowing their land for the next

harvest. As a result, in the coming months, serious seed shortages will

likely be the most pressing problem in the district. Without external

assistance, and notwithstanding next years weather 
conditions, it is clear

that most families will not be able to sow much land, thus prompting

another serious food deficit next year. Following the announcement of a

state of emergency in the area, food items were distributed by FOCUS to over 3000 families from 22 villages and by SNI to over 2,000 families from

16 villages. As of today 3,527 families from 33 villages $(40.5 \%$ of the overall population of the district estimated to 8,694 families) have not been covered by any food distribution.

The main problem in terms of water and sanitation in the district is the lack of availability of drinking water. Except for 2 villages located in the south of the district, all villages rely on spring water, and some of them are located far from the main settlements. With the drought, many of these springs have dried up or considerably reduced their outputs. OXFAM

has implemented a successful programme in the area covering 19 villages by building water supply systems. In those villages which were not covered by

OXFAM, ACTED determined that the situation of drinking water was of concern

in 25 villages, and critical in 12 .

As noted by the MSF survey in March 2001, the number of deaths linked with

the emergency situation is on the rise; according to he ACTED survey,

approximately 410 children have died from diseases and malnutrition induced

by drought in the Shar-i-Buzurg district since January 2001.

The survey

also confirmed the numbers given by other NGOs regarding malnutrition

figures. Approximately $30 \%$ of the children of the sample selected proved

to be suffering from nutrition deficiency, and some from severe malnutrition (up to $5 \%$ ), and required medical care. The district has only one clinic and has no specialised facilities designed to 
deal with food

deficiency. Moreover, no Mother Child Health $(\mathrm{MCH})$ facility exists in the

area, the nearest one being located in distant Rustaq,

(anywhere between 5

hours for the closest village to three days horse ride or

walk for the most

remote villages). The poor access to drinking water in many

villages also

has an impact on the incidence of water borne diseases, as

exemplified by

the high number of diarrhoea and dysentery in many areas.

The situation in

Shar-I-Buzurg district will probably continue to worsen as

the food

deficit, aggravated by a poor harvest, take their toll on

the local

population, with a direct impact on the health situation. It

must be

underlined that similar situations are reported in many

other more remote

districts in northern Badakhshan, where few or no aid

organisations are

operating because of access and logistical constraints. In

the end, the

ability of the aid community to address the short and mid-term needs of the

local population of Shar-I-Buzurg and other drought affected areas in

crisis will have a direct impact on the decision of the

vulnerable segments

of the local populations to stay in the area or go swell the number of IDPs

and refugees.

Q. Is this far too much information? Please cut what is irrelevant.

In April 2001 Save the Children conducted a nutrition assessment in Faryab

provinces mountainous Kohistan district, a region

inaccessible by road

during the winter. The assessment found that mortality rates had reached

alarming levels in the four preceding months, with the crude mortality rate

of 2.6 per 10,000 per day and the under-five mortality rate

of 5.9 per

10,000 per day. In this period, mortality was due to acute

respiratory

infections and outbreaks of measles and bloody diarrhoea, 
made worse by

drought conditions and economic insecurity. Half of the reported deaths

were of children under 5 years old. The report reveals nutrition is a

serious problem, with acute malnutrition highest among children under 30

months. Residents in a number of villages are afflicted with scurvy, or

vitamin $\mathrm{C}$ deficiency, due to the unavailability of fruits, vegetables, and

even wild foods during the districts snowbound winter. The absence of

medical care and clean water in the district exacerbates an

already dire

health picture. Most families in this remote area have

depleted their

supplies of grain and sold most of their livestock. Many

people are selling

their land, becoming displaced, begging and taking loans

with high interest

to survive. Many men have left their homes to seek work in neighbouring

Iran. Moreover, daughters are being given for marriage at a lower age and

for a bride price six times lower than normal.

VI. Internally Displaced and Refugee Women please cut where irrelevant

More than half a million people the vast majority of whom are women and

children, are estimated to have left their homes and become newly displaced

during 2000 and early 2001, heading towards impoverished cities and other

areas. They have flocked to the bigger towns and cities or crossed the

border into Iran and Pakistan According to a report of 31

January 2001 by

the Office of the United Nations Coordinator for

Afghanistan, over 110

displaced persons in camps in Herat died due to extreme cold on the night

of 29/30 January. The same report estimated the number of displaced persons

in six camps outside Herat City to be approximately 80,000 , families having

started to leave their homes as early as June 2000 because of the severe

drought which resulted in crop losses averaging 75 per cent 
and a 50 per

cent reduction in livestock assets.

According to UNHCR officials in Pakistan, there has been a marked increase

in new arrivals, the total number estimated to have arrived

since mid-2000

is around 170,000 and a significant number of these are from northern

Afghanistan. The refugee flows are caused by the interrelated impact of

conflict, drought, and hunger. The situation of refugees is

aggravated by

the imposition of the ban on new arrivals by Pakistan which, having hosted

the single largest and one of the oldest refugee populations

in the world,

has argued that it simply cannot cope with new inflows. This

has resulted

in the suspension by regional authorities of the

verification process

commenced on 25 January 2001 by UNHCR to determine those who

are most

vulnerable and in need of urgent assistance, followed by the

Government

decision that all undocumented Afghans would be subject to

deportation.

Following these decisions, there are reports of forcible

deportation of

thousands of Afghans.

Reports received in regard to the IDP compound in the former

Soviet Embassy

in Kabul are of concern. The Taliban controls the access

of the IDPs to

the city and women are reportedly not permitted to

leave the area

without a written medical note to seek health

care. The living

conditions in the compound, are poor clean water and

adequate toilet

facilities are lacking. Even though the IDP

population was largely

composed of women and children, reportedly more

toilets had been

constructed for men than for women. The women

interviewed confirmed

their fragile and vulnerable states. Many women had been

separated from

their husbands some of whom they feared had been killed 
in the fighting

and others were detained in prison.

According to reports at the end of June 2001 the number of the IDPs in the

Khoja Bahauddin camps has increased. Approximately 300 new families from

Khwagaghar, Dasht-I-Archi, and southern Dasht-I-Qala, and Shar-I-Buzurg

have arrived. Most of the families are without

shelter. Displacement

from Rustaq and Chah $A b$ because of the weather has also been noted. WFP

screened the IDP list for Faizabad and identified 1,400

out of 2,051 who

constituted genuine IDPs. After agreement with the

authorities, WFP will

conduct a food distribution and move on to Keshem, Argu,

Rustaq and Chah

$\mathrm{Ab}$ districts. An al-location for 5,000 families is

available of 100

kilos per family. In addition, 1,000 IDP children in

schools in Faizabad

will receive wheat through the Food-for- Education

project.

The Guiding Principles on Internal Displacement specifically recognize the

particular concerns of IDP women and girls and call for

measures to protect

them. They call for IDP women to be included in all phases

of planning and

distribution of humanitarian assistance, and for IDPs to be

protected from

all forms of violence including rape and other

gender-specific violence,

including forced prostitution. An international NGO has

encouraged aid

agencies to take new approaches to assisting internally

displaced persons;

in particular, to focus greater attention on protection, on

sustaining

livelihoods, on self-determination and independence-building activities, on

involving women in the peace and reconciliation process and on managing

community development activities. It has also made the

following

recommendations, which merit serious consideration: 
(a) Although extremely difficult in war zones, sex disaggregated data

collection is crucial to providing effective

programming for

internally displaced people. Access to good

representative data

prevents mistakes like the example cited above where

more toilets

for men were built in a population of mostly women

and children.

(b) Agencies need to engage gender specialists to

assess internally

displaced persons settings so that appropriate

actions can be taken

to address the different needs and rights of women and men.

(c) Given that the level of literacy of women in many displacement

situations is low, information on entitlements and programming should

be provided in oral or visual formats for non-literate women.

(d) Lessons-learned documentation from various internally displaced

settings need to be published and distributed to enable programmes

to be better implemented and past mistakes avoided.

(e) Internally displaced women must be involved in planning,

designing and monitoring of programmes. In cases where displaced

women have input and ownership in programme activities,

as well as in

reintegration processes, the risks of gender rights

abuses occurring

are reduced.

(e) The Guiding Principles on Internal Displacement

should be

translated into local languages and distributed to women.

(f) Special arrangements should be made to distribute food directly

to women and to involve them in the process of distribution and monitoring.

(g) United Nations agencies should consider promoting an inter-agency

mechanism to ensure institutional responsibility for gender in

situations of displacement. 
(h) More attention is needed on programmes that encourage

self-determination and community development efforts and less on short-term emergency measures.

(i) Periodic gender audits should be commissioned by the lead agency

in a given setting of internal displacement to assure that gender issues are addressed according to international standards and

guidelines.

\section{VII.Education}

After more than two decades of conflict, Afghanistan has some of the worst education indicators in the world according to a UNICEF Afghanistan paper entitled "Education - a chronic emergency in Afghanistan". It records how access is low at all levels, especially for girls but also for boys.

According to recent UNESCO data, as few as three per cent of Afghan girls and 39 per cent of boys in the relevant age groups may be attending some form of primary education, the quality of much of which remains poor.

In May 2001 a setback to the provision of education came when six schools

run by a Turkish Islamic group were shut down in Afghanistan. (endnote BBC

NEWS 17 May, 2001) In a country where the state education system is

suffering from a chronic lack of resources, the Turkish schools were said to be rare centres of educational excellence. Some 2,000 pupils attended the six Turkish schools, which were free. They had a curriculum that was strong in science and languages, as well as religion, and they were well resourced. Almost uniquely in Afghanistan, each school had a laboratory and

a library It is reported that they had been ready to accept many of the Taleban's demands - that teachers should grow long beards, for example, and 
pupils wear turbans - but they would not agree to hand over their budget to

the Taleban. The Taleban had reportedly wanted all the Turkish teachers to leave the country, leaving just one official who would hand the budget over

to the Taleban education ministry for it to distribute.

$Q$. did they provide education for girls? it wasn't clear from the text, if not we should cut it out.

VIII. United Nations activities in the context of the principled approach

I refer to point 2 of WFP Afghanistan comments re DAW's report :

The gender training provided to WFP took place two years ago (June 1999).

Have there not been more recent activities to which the report can refer?

(In this regard, WFP Afghanistan has organized its own gender workshops)

Q. If there has been more recent gender training/activities which should be

included please ask WFP to send me a short paragraph on it asap so it can

be inserted into the text. Thanks.

A two-day joint (date) United Nations Development Programme (UNDP) and

World Bank conference was organised to work more into the mainstream of

assistance programmes for Afghanistan. Studies on

Afghanistan's

international trade relations and on the socio-economic

impact of mine

action, along with findings of earlier workshops and

conferences on basic

education, health service delivery and food security

strategy in

Afghanistan, were discussed at them conference. Other studies include those

on the socio-economic impact of remittances on the Afghan

family and

household (in progress) and an overview of agricultural production in the

country. The project also supported a capacity building programme in

Peshawar for about 600 Afghan women working with NGOs. At the conclusion, 
donor, NGO, and UN representatives urged the World Bank to expand the range

of its analytical works in partnership with UNDP and embark on a second

phase of the Watching Brief strategy.

IVX. The operating space for the UN and aid agencies is narrowing

In May 2001 four days of intensive talks between the UN and the Taliban in

the Afghan capital, Kabul, broke down without reaching agreement on the

crucial issue of using women to conduct a survey of the

capital's most

vulnerable people. The ensuing stalemate could result in the closure of the

UN's bakeries, which feed almost 300,000 people in Kabul, and ultimately

puts the fate of the UN's other humanitarian programmes in the balance.

(endnote ISLAMABAD, 30 May (IRIN))

On 25 May the World Food Programme (WFP) announced that it would have to suspend its bakery programme by 15 June unless the Taliban allowed a survey

to be conducted to identify the capital's "most needy". The current list of

approved recipients of the bakery project is outdated and the UN claims

many hungry people are having to do without. WFP says it needs to hire

between 20 and 30 Afghan women to conduct the survey, but the Taliban

refuse to allow the UN to hire local women.

In a meeting with a nine-member UN team, the Taliban foreign minister,

Mowlawi Wakil Ahmad Mutawakkil, suggested that if the

five-year-old

bakeries were forced to close, the Islamic Emirate (Taliban)

authorities

could take over the running of the programme, an option

which was

applauded. It was welcomed as an effort by the Taliban

authorities to start

taking care of their own people and start to feed them. The

Taliban also

mooted two alternative options. The first was to hire men to 
conduct the

survey, in spite of the fact that, under Islamic Emirate

rules, men cannot

talk to women. The second option was to hire women of

Pakistani, Tajik or

Iranian nationality. The UN opposed both proposals. Q. Has

the issue been

resolved? what is the outcome?

The deadlock comes amid what has been called a "narrowing of the space

available for relief agencies to operate effectively in

Afghanistan". The

UN has expressed its serious concern during the meetings

with Taliban

ministers over what is called harassment from "guests" - an

increasing

number of visitors to Afghanistan from the Gulf and other

countries who had

been directing abuse and sometimes death threats at aid

workers and UN

staff. The cases had escalated to such a degree that

international staff

are no longer able to walk freely, and had resorted to

travelling in

vehicles to avoid such incidents. Equally, the conduct of

the Taliban's

religious police from the Ministry for the Promotion of

Virtue and the

Prevention of Vice had become increasingly hardline,

engaging in

indiscriminate arrests.

The operating space for the UN and aid agencies is narrowing it is felt

that the international community must make it clear that:

these are the

conditions under which they can operate, and if that is not acceptable,

then, unfortunately, we will have to close down, or stop or

suspend

programmes. Whereas the WFP bakeries could be the immediate casualty, the

risk of other UN humanitarian programmes also closing has

not been ruled

out if the trend of increased harassment and obstacles

continues.

Meanwhile, the UN did succeed in reaching agreement with the

Taliban on a 
number of other "basic operational requirements", including the need for

free and unhindered access for aid workers, security of staff, the ability

to independently assess and monitor programmes, and the need for such programmes to be based on "universality, impartiality and

neutrality". The UN and NGOs have underscored that they are bound by

certain basic principles set by the international community.

The Taleban authorities in Afghanistan have ordered female aid workers to

stop driving. A letter issued by the Taleban religious

police in May says

that foreign women driving cars in Afghan cities "is against

Afghan

traditions and has a negative impact on the environment."

It states that

in future, foreign women must not drive cars and must "abide

by the

regulations of the Islamic Emirate (of Afghanistan)".

(endnoteBBC NEWS,

Thursday, 31 May, 2001)

The move came amid increasing tension between the Taleban and the UN over

the treatment of foreign aid workers and the use of women

employees. It is

not clear how much impact this edict will actually have as

the UN and

larger non-governmental organisations who can employ Afghan

male drivers,

however it is thought that it could affect smaller aid

organisations

On 24 June 2001 police from the Ministry for the Prevention of Vice and

Promotion of Virtue raided an Italian-funded emergency hospital in Kabul,

beating several staff members and forcing the hospital to suspend

operations because male and female staff allegedly mixed in the dining area

and operating wards. Taliban authorities have also recently blocked the

delivery of humanitarian aid to large parts of the Hazarajat region, which

is populated mainly by Shi'a Muslims and includes centers of armed 
opposition activity.

The Under-Secretary-General for Humanitarian Affairs and Emergency Relief

Co-ordinator has expressed his concern about the increasing harassment and

abuse of Afghan national staff of the UN and NGO community, and

restrictions against programmes that attempt to help women as well as men.

Humanitarian aid currently reaches well over four million people in

Afghanistan, one of the world's worst crisis areas. Yet the recent pattern

of harassment represents a general narrowing of space available for

humanitarian agencies to operate effectively. Such behaviour may limit the ability of aid agencies to continue helping Afghans in need.

He called upon

the Taliban to take immediate steps to improve the working environment of

the humanitarian community. (endnote27 June Weekly Update.)

\section{VX. Concluding remarks/recommendations}

The Afghanistan Support Group paper succinctly depicts the situation which

needs to be addressed if human rights are to be protected against

further deterioration:

"It is increasingly apparent that the coping capacity of those who are

most vulnerable has been severely weakened as a result

of the war; the

majority of the population struggles to survive at near

subsistence

levels. The situation of females, including in

particular female-headed

households, is of particular concern given the many old and new

restrictions that limit their ability to provide for

themselves and

their families. Indeed, for women and men alike there

are very few job

opportunities outside the subsistence economy; for many, the only

available option is the criminalized economy or 
re-location to another

area. Afghanistan's socio-economic indicators are well

known and are

likely to get worse as the drought takes its toll and

the underlying

causes of poverty and underdevelopment are largely

ignored. It is this

reality - coupled with the knowledge of what was

possible in pre-war

Afghanistan - which should motivate the international

community to

tackle the dynamics which contribute to a worsening of the crisis and

with it a further deterioration of the human rights situation."

$\varnothing$ A set of UN policy guidelines to deal with issues such as

international women being asked to leave meetings by the Taliban, national

women's security and mobility need to be developed.

$\varnothing$ Women must be brought into all levels of the United

Nations.

Furthermore those with gender-specific expertise must be included in senior

management if the United Nations is to develop appropriate and effective

policies to protect and assist women and girls during and after armed

conflict.

$\varnothing$

Norah please add here anything that you would like to see in the

sub-commission resolution conclusions/recommendations etc.. 